\title{
Factors Affecting the Financial Performance of Property Andreal Estate Companies Listed at Indonesia Stock Exchange
}

\author{
Tita Deitiana, Lionel Greg Habibuw
}

Department of Management, Trisakti School of Management, Jl. Kyai tapa No. 20, Grogol, Jakarta Barat, 11440, INDONESIA

\begin{abstract}
Financial performance is one of the factors used by investors in buying shares. For companies, improving financial performance is a must in order to keep the company's stock attractive to investors. Financial statements published by the company are a reflection of the company's financial performance. These financial statements are the result of the accounting process that is intended to provide the financial information of a company. The financial information can be used by users for making investment decisions.

Performance is the result of the fulfillment of the tasks assigned. Company performance describes how individualsin the company tries to achieve a goal. Company performance illustrates the magnitude of the results in a process that has been achieved compared with the company's goal. The purpose of this study is to find out factors determining financial performance.

The objects of this study are property and real estate companies listed on the Indonesia Stock Exchange (IDX) during the period of 2007 - 2012. Data for this study stems from secondary data gathered by analyzing financial statement of the sample companies. The data is then analyzed with Eviews 7.2 Panel Data Regression Analysis.

The research findings can be summarized as follows. Variable leverage and Firm Age has an effect on financial performance. Other variables like liquidity, Firm Size, Managerial Ownership and Block holder Ownership have no effect on financial performance.
\end{abstract}

Keywords: Financial Performance, Leverage, Liquidity, Firm Size, Firm Age, Ownership JEL Classification code: G31

\section{INTRODUCTION}

Performance is the result of the fulfillment of the tasks assigned. Company performance describes how individuals in the company try to achieve a goal. Company performance illustrates the magnitude of the results in a process that has been achieved compared with the company's goal. Company's performance is evaluated in three dimensions. The first dimension is company's productivity, or processing inputs into outputs efficiently. The second is profitability dimension, or the level of which company's earnings are bigger than its costs. The third dimension is market premium, or the level of which company's market value is exceeding its book value (Wellage, 2012).

Financial performance plays an important role in the company performance that is expressed in monetary term. Financial performance emphasizes on variables related directly to the financial report. Before investing their funds, investors should first know about the performance of the company. The simplest way to determine the performance of the company is to look at the company's financial statement. In this intense competition among the companies, the company is expected to be able to maintain and improve its performance in order to compete with others. Indonesia's property and real estate sector has been experiencing seemingly unstoppable growth for the last decade.

The figure 1 showed that Property indices have increased continuously from the beginning of January 2011 until the end of December 2012. The increasing seems adorable from below zero amount to the amount of $60.11 \%$ in two years. The Development of Real Estate industry in Indonesia has increased in this decade. It is seen from the rampant development that greatly increased in the field of property throughout Indonesia. The study importance emerges from the fact that Real Estate Industry plays a significant role in enhancing the country economy. It has also been the primary concern of business practitioners in all types of organizations since financial performance has implications to organization's health and ultimately its survival. Empirical literature examines how financial and nonfinancial factors, such as leverage, liquidity, size, age, Ownership have an influence on the firms' financial performance. The researcher has chosen these factors because they are the most appropriate ones for Indonesian context among many factors affecting the financial performance. On the other hand, these factors can be easily measured by using the data that is affordable by Property and Real Estate companies. 


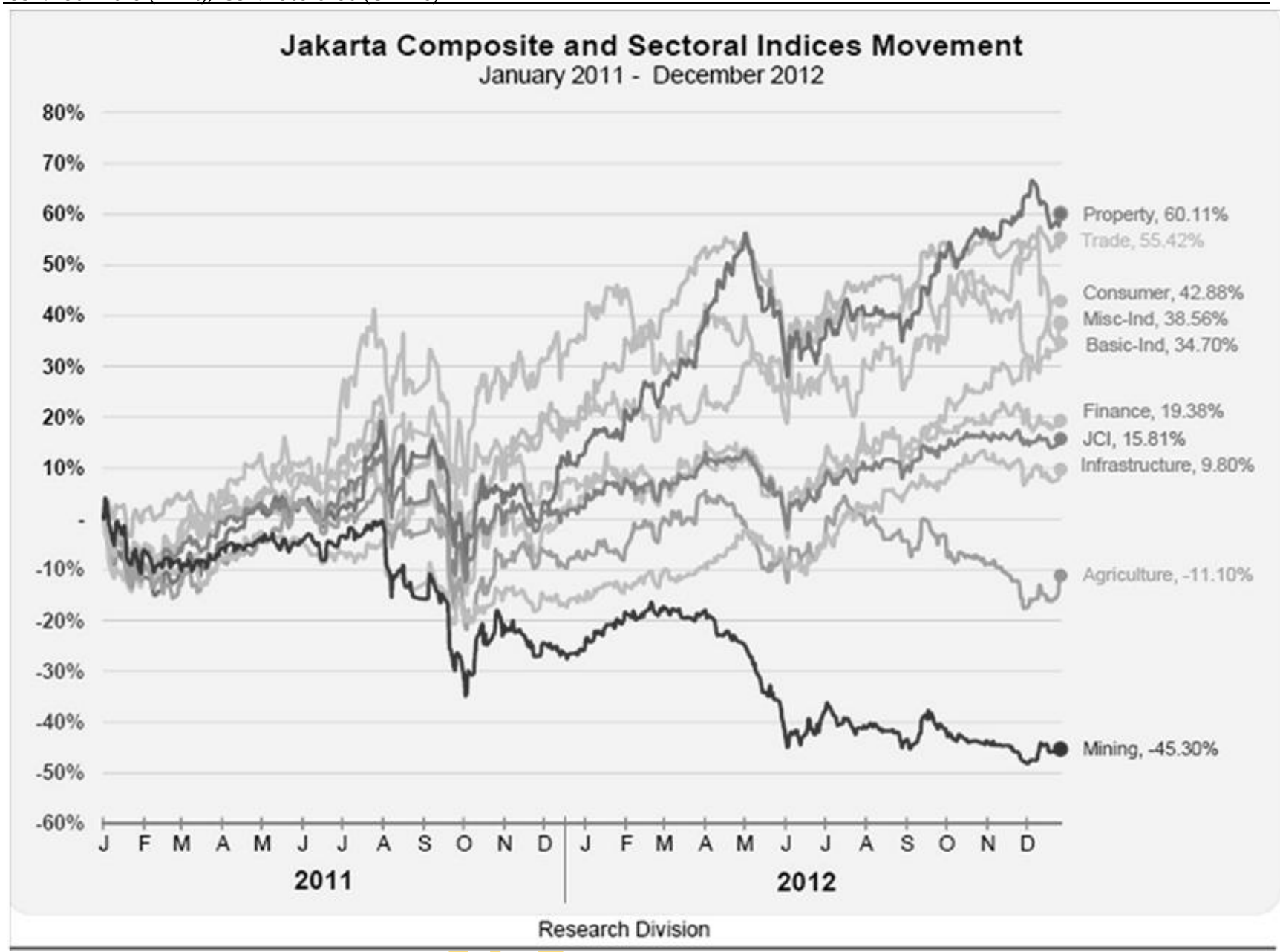

Figure 1 Source: JSX

It has also been the primary concern of business practitioners in all types of organizations since financial performance has implications to organization's health and ultimately its survival. Empirical literature examines how financial and non-financial factors, such as leverage, liquidity, size, age, Ownership have an influence on the firms' financial performance.

The researcher has chosen these factors because they are the most appropriate ones for Indonesian context among many factors affecting the financial performance. On the other hand, these factors can be easily measured by using the data that is affordable by Property and Real Estate companies.

There are several factors affecting financial performance such as Leverage, Liquidity, Firm size, Firm age, Managerial ownership, and Block holder ownership. The first factor affecting financial performance is Leverage.

Firms that are highly leveraged may be at risk of bankruptcy if they can't make payments on their liabilities; they also are hard to find new lenders in the future. Leverage is not always bad; it will increase the shareholders' return on their investment. There is a positive relationship between leverage and financial performance. But in fact, when leverage was increased, ROA seems decrease or vice versa in PT Bekasi Asri Pemula, Tbk (2010-2011) ROA from 0,1065 to 0,0513 and DER from 0,82 to 0,83, PT Bhuwanatala Indah Permai Tbk (2008-2009) ROA from -0,1897 to -0,1018 and DER from 0,81 to 0,96, PT Intiland Development Tbk (2011-2012) ROA from 0,0349 to 0,0333 and DER from 5,23 to 5,29.

The next factor affecting financial performance is Liquidity. A firm can use their liquid assets to investment and also finance its activities. Higher liquidity helps the firm to cope with its obligation during low earnings period. There is a positive relationship between liquidity and financial performance. But in fact, when liquidity was increased, ROA seems decrease or vice versa in PT Jaya Real Property Tbk (2008-2009) ROA from 0,0949 to 0,0891 and CR 2,771 to 3,932, PT Global Land Development Tbk (2009-2010) ROA from 0,0611 to 0,081 and CR 9,665 to 9,14, and PT Intiland Development Tbk (2008-2009) ROA from 0,0213 to 0,0274 and CR from 1,3008 to 1,1275 .

Firm size is also affecting financial performance. Large firm is more efficient than small firm. Small firm also have less power than large firm, so they can't easily compete in a highly competitive markets. When the firm 
Asian Business Review, Volume 5, Number 2/2015 (Issue 11)

ISSN 2304-2613 (Print); ISSN 2305-8730 (Online)

become larger, they might suffer from inefficiencies, however, makes the financial performance became ramshackle. There is a positive relationship between firm size and financial performance. But in fact, when firm size was increased, ROA seems decrease or vice versa in PT Pakuwon Jati Tbk (2007-2008) ROA from 0,0268 to 0,0095 and Total Assets from 3.115.215.408.000 to 3.562.501.143.000, PT Jaya Real Property Tbk (2008-2009) ROA from 0,0949 to 0,0891 and Total Assets from 2.211.213.226.000 to 2.585.475.177.000, and PT BEKASI ASRI PEMULA, Tbk (2007-2008) ROA from 0,0067 to 0,0271 and Total Assets from 137.498.932.263 to 127.212.980.516.

Firm age has been considered as a factor that affecting financial performance. Older firms are more experienced. They also benefit from reputation effects, which allow them to get a higher income. But on the other hands, they are inflexible and cannot appreciate changes in the environment. There is a positive relationship between firm age and financial performance. But in fact, when firm age was increased, ROA seems decrease or vice versa in PT Jaya Real Property Tbk (2008-2009) ROA from 0,0949 to 0,0891 and Firm Age from 29 to 30, PT Global Land Development Tbk (2010-2011) ROA from 0,081 to 0,0269 and Firm Age from 20 to 21, and PT Pakuwon Jati Tbk (2010-2011) ROA from 0,0979 to 0,0818 and Firm Age from 28 to 29.

The last factor affecting financial performance is Ownership structure. In this research ownership structure is divided into two, Managerial ownership and Block holder ownership.

Large shareholder can affect firm considerably with the help of their substantial voting power. Large owner can also control management and implement their decision and recommendation. Managerial ownership is also considered as one of the factors affecting financial performance for its role as the decision maker in this case for the welfare of the shareholders through a good financial performance.

There is a positive relationship between ownership structure and financial performance. But in fact, when Block holder or Managerial ownership was increased, ROA seems decrease or vice versa in PT Intiland Development Tbk (2009-20010) ROA 0,0274 to 0,0933 and $\mathrm{MO}$ from $0,00304 \%$ to $0,001 \%$ also $\mathrm{BO}$ from $86,47 \%$ to $60,75 \%$, PT Jaya Real Property Tbk (2008-2009) ROA from 0,0949 to 0,0891 and $\mathrm{MO}$ from $0,001 \%$ to $0,01 \%$ also BO from $76,55 \%$ to $77,98 \%$, and PT Global Land Development Tbk (2009-2010) ROA from 0,0611 to 0,081 and $\mathrm{BO}$ from $81,43 \%$ to $58,50 \%$.

\section{TheORETICAL FrameWORK AND HyPOTHESIS}

\section{Financial Performance}

Performance is the result of the fulfillment of the task assigned. Company performance describes how each individual on the company try to achieve a company goal. Company performance illustrates the magnitude of the result in a process that has been achieved compared with the company's goal. Performance will be a function of the effectiveness of contractual mechanisms in attracting, retaining and controlling managerial talent in ways that maximize owners' wealth according to Copeland $(2005,443)$. Financial performance is described by Return on Assets. The explanations are as follow.

According to Gitman (2012, 81),"ROA Measures the overall effectiveness of management in generating profits with its available assets; also called the Return On Investment (ROI)".

According to Bodie et al (2011, 812),"ROA which measures profitability for all contributors of capital, is defined as earnings before interest and taxes divided by total assets".

According to Ross et al $(2009,53),{ }^{\prime}$ ROA is A measure of profit per dollar of assets".

From the statement above, we can conclude that ROA Measures the overall effectiveness of management in generating profit per dollar by relating net incone to total assets.

\section{Leverage (DER)}

According to Gitman (2009, 546), "Leverage is result from the use of fixed cost assets or funds to magnify returns to the firm's owners". Leverage described by proxy Debt to equity ratio. The explanations are as follows.

According to Gitman (2009, 260), “Debt/Equity Ratio is another computation that determines the entity's longterm debt paying ability. This computation compares the total debt with the total shareholder's equity".

According to Brown and Reily (2009, 291), "The proportion of debt ratios indicates what proportion of the firm capital is derived from debt compared to other sources of capital, such as preferred stock, common stock, and retained earnings".

According to Ross $(2009,49)$, Debt to Equity Ratio is the Total liabilities of firm divided by its total equity.

From the statement above, we can conclude that Debt to Equity Ratio is a solvency measure that indicates the percentage of company's equity is provided by creditors.

$\mathrm{Ha}_{1}$ : There is a significant effect of Leverage to Financial Performance

\section{Liquidity (CR)}

According to Ross et al $(2009,22)$,"Liquidity refers to the ease and quickness with which assets can be converted to cash (without significant loss in value)". Liquidity described by proxy current ratio. The explanations are as follows.

According to Gitman (2012, 71),"Current Ratio is A measure of liquidity calculated by dividing the firm's current assets by its current liabilities". 
According to Bodie et al $(2011,819)$, "Current Ratio, This ratio measures the ability of the firm to pay off its current liabilities by liquidating its current assets (i.e., turning them into cash). It indicates the firm's ability to avoid in solvency in the short run".

According to Ross et al (2009, 48), Current Ratio is A firms current assets divided by its current liabilities.

From the statement above, we can conclude that Current Ratio is a liquidity measure that indicates the ability of the firm to pay off its current liabilities.

$\mathrm{Ha}_{2}$ : There is a significant effect of Liquidity to Financial Performance

\section{Firm Size}

According to Brown (2009, 161), "Firm size refers to how large or small a firm is measures by the firm's market value. Therefore, firm size can be concluded as how large a company is reflected by its total asset, sales, or market capitalization".

According to White et al (2003, 178), "Size effect Smaller firms (measured by total assets or total capitalization) tend to out- perform the market even when returns are adjusted for risk". According to Haugen (2001, 606), "Firm size is a picture of large or small companies that appear in the value of total assets, and its measured by logarithm of total assets".

From the statement above, we can conclude that Firm size is describe about how large or small of a company measured by its total assets or by its total capitalization.

$\mathrm{Ha}_{3}$ : There is a significant effect of Firm Size to Financial Performance.

\section{Firm Age}

According to Ross (2009), "Age of firm is the number of years to date of establish".

According to Lee (2008), "Firms age is the actual existence of the firm since starting year of its operation". According to Keown (2005), "Older firms may also benefit from reputation effects, which allow them to earn a higher margin on sales.

From the statement above, we can conclude that firm age is the period of time where the company established and in relations to image of the firm.

$\mathrm{Ha}_{4}$ : There is a significant effect of Firm Age to Financial Performance.

\section{Ownership Structure}

According to Elmans (2012),"Ownership structure of listed firms is defined as the distribution of shares to amongst owners".

\section{Managerial Ownership}

According to Domash (2010, 218), “Managerial ownership is a percentage of stock held by company key officers, such as commissary and board of director from share outstanding".

According to Damodaran (2002, 143), "Managerial ownership is an ownership percentage which having by an officers or director of a company".

According to Wellage et al (2012), "Managerial ownership refers to the percentage of share owned by commissioner and board of director from total share outstanding".

From the statement above, we can conclude that Managerial Ownership is the proportion of stock held by key officers and executive directors.

\section{$\mathrm{Ha}_{5}$ : There is a significant effect of Managerial Ownership} to Financial Performance.

\section{Blockholder Ownership}

According to Elmans (2012)," Blockholder ownership is the proportion of ordinary shares owned by substantial shareholders (with equity of $5 \%$ or more)".

According to Aguilera (2004), "Define blockholder such as families, institutional investors or industrial banks with socially constructed interests in a company".

According to Thomsen, Pedersen, and Kurt Kvist (2006). Blockholder is defined as a shareholder whose ownership is at least $5 \%$ of the shares of the company. While blockholders ownership is defined as the fractional change of "closely held shares". Closely held shares are shares held by the blockholder, including ownership of company stock by employees, directors and their families, trusts, pension funds, shares held by other firms and individuals, which has a shareholding of more than $5 \%$.Blockholders are the owner of a large amount of a company's shares and/ or bonds or block. In terms of shares, these owners are often able to influence the company with the voting rights awarded with their holding.

From the statement above, we can conclude that Blockholder Ownership is the proportion of stock owned by substantial shareholders.

$\mathrm{Ha}_{6}$ : There is a significant effect of Blockholder Ownership to Financial Performance.

Based on previous description, the issues and objectives of study developed a framework thinking process as shown below: 


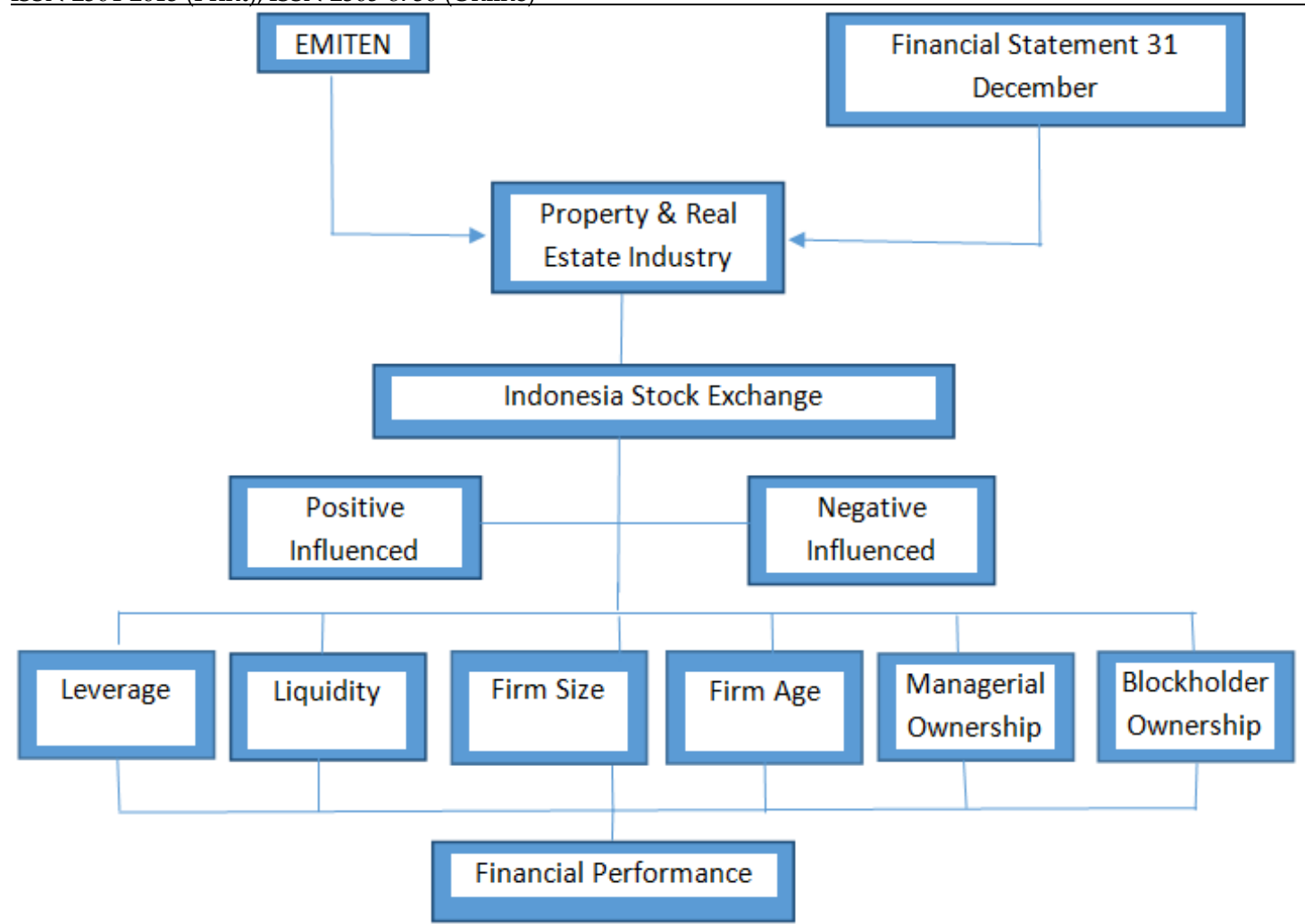

Chart 1: Thinking Framework

\section{ReseARCH Method}

Form of research used to examine the financial performance is Causal Study, According to Sekaran (2009, 110) A study in which the researcher wants to delineate the cause of one or more problems. In this study there are six independent variables, that is Leverage, Liquidity, Firm Age, Firm Size, Managerial Ownership, and Blockholder Ownership. Whereas the dependent variable is Financial Performance. A researcher using a Panel Data, According to Verbeek $(2012,372)$ A panel data set contains repeated observations over the same units (Individuals, household, firms), collected over a number of periods.

Object of research used in this study are companies engaged in the property and real estate industry listed in the Indonesia Stock Exchange (ISE) period 2007-2012. The selection of the sample of the study conducted using Non-Probability sampling technique, which is Purposive Sampling Method. According to Zikmund et al (2010, 396),"Judgment (Purposive) Sampling is A nonprobability sampling technique in which an experienced individual selects the sample based on personal judgment about some appropriate characteristic of the sample member".

According to Anderson et al (2011, 290), Judgment Sampling is A nonprobability method of sampling whereby elements are selected for the sample based on the judgment of the person doing the study. In this approach, the person most knowledgeable on the subject of the study selects elements of the population that he or she feels are most representative of the population. Often this method is a relatively easy way of selecting. Therefore, the consideration used to determine the number of samples that represent the population is as follows:

Property and real estate companies listed at Indonesia Stock Exchange (ISE) Period 2007 - 2012. Property and real estate companies that publish the financial statement at December 31 each year during the period 2007 - 2012. The financial statement with the list of shareholdersin the year of the study, the reporting year 2007 - 2012.

Using Rupiahs on its financial statement.

Table 1

Sampling Procedures

\begin{tabular}{|l|c|}
\hline Sampling Criteria & Total \\
\hline Number of firms listed at IDX from 2007 - 2012 & 37 \\
\hline $\begin{array}{l}\text { Number of firms does not consistently publish data } \\
\text { of its financial statements each year of December 31 } \\
\text { from } 2007 \text { to } 2012\end{array}$ & $(9)$ \\
\hline $\begin{array}{l}\text { Number of firms does not consistently publish data } \\
\text { of its financial statements with the list of } \\
\text { shareholders in the year of the study, the reporting } \\
\text { year 2007 - 2012. }\end{array}$ & $(22)$ \\
\hline $\begin{array}{l}\text { Property and Real Estate companies which fulfill the } \\
\text { criteria }\end{array}$ & 6 \\
\hline Research period 2007 to 2012 (Number of years) & 6 Years \\
\hline Total data used as samples & 36 Data \\
\hline
\end{tabular}

Source: Indonesia Stock Exchange 2007 - 2012 
Operational Definition and the Measurement of Scale Financial Performance

Financial performance is measured by ROA. According to Ross et al $(2009,53)$, , ROA is A measure of profit per dollar of assets". The formula is as follows:

$$
\text { Return On Assets }=\frac{\text { Net Income }}{\text { Total Assets }}
$$

\section{Leverage}

According to Gitman $(2009,546)$, "Leverage is result from the use of fixed cost assets or funds to magnify returns to the firm's owners". In this study the leverage is measured by Debt-to-Equity Ratio (DER). According to Ross $(2009,49)$, Debt to Equity Ratio is the Total liabilities of firm divided by its total equity. The formula is as follows:

$$
\text { Debt }- \text { to }- \text { EquityRatio }=\frac{\text { Total Debt }}{\text { Total Equity }}
$$

\section{Liquidity}

According to Ross et al $(2009,22)$, "Liquidity refers to the ease and quickness with which assets can be converted to cash (without significant loss in value)". In this study the liquidity is measured by Current Ratio (CR). The formula is as follows:

$$
\text { CurrentRatio }=\frac{\text { Current Assets }}{\text { Current Liabilities }}
$$

\section{Firm Size}

According to White et al $(2003,178)$, size effect Smaller firms (measured by total assets or total capitalization) tend to outperform the market even when returns are adjusted for risk. As described before, Firm Size is measured by the total assets of a firm. The formula is as follows:

Firm Size $=$ Logarithm Natural (Ln) of Total Asset

\section{Firm Age}

According to Kakani., Saha," and Reddy (2001) Regarding firm age, older firms are more experienced, have enjoyed the benefits of learning, are not prone to the liabilities of newness, and can, therefore, enjoy superior performance. Older firms may also benefit from reputation effects, which allow them to earn a higher margin on sales. In this study the Firm Age is measured by the number of years since establishment. The formula is as follows:

Firm Age $=$ The number of years since establishment

\section{Managerial Ownership}

According to Eng (2003),"Managerial ownership is the proportion of ordinary shares held by CEO and executive directors and shares in which they are deemed to have interest". In this study the managerial ownership is measured by the proportion of stock held by the person on managerial position. The formula is as follows:

ManagerialOwnership $=\frac{\text { Number of Managerial Stocks }}{\text { Number of Stock Outstanding }} \times 100 \%$

Blackholder Ownership

According to Eng (2003)," Blockholder ownership is the proportion of ordinary shares owned by substantial shareholders (with equity of $5 \%$ or more)". In this study Blockholder Ownership is measured by the proportion of stock owned by substantial shareholder. The formula is as follows:

BlockholderOwnership $=\frac{\text { Number of Blockholder's Stocks }}{\text { Number of Stock Outstanding }} \times 100 \%$

\section{Data Collection Techniques}

Data collected in this study is a secondary data, which sourced from financial statement of company that is used as sample. According to Sekaran $(2009,184)$ Secondary source of data refer to information gathered by someone other than the researcher conducting the current study. Such data can be internal or external to the organization and accessed through the internet or perusal of recorded of published information. The data is obtained from the publication of the financial statement of services companies listed at Indonesia Stock Exchange (ISE).

\section{Data Analysis Method \\ Descriptive Statistic}

Descriptive statistics are used in this study. According to Anderson $(2011,13)$ Descriptive statistics is summaries of data, which may be tabular, graphical, or numerical. In this research, descriptive statistic methods that are used such as number of samples, mean, maximum, minimum, and standard deviations.

\section{Panel Data Analysis Technique (Panel Model Selection)}

Panel data regression as data analysis method with Statistical data processing program are used in this study. According to Gujarati (2009, 591) Pooled data (pooling oftime series and cross-sectional observations), combination of time seriesand cross-section data. Panel data can enrich empirical analysis in ways that may not be possible if we use only cross-section or time series data.

There is several estimation technique approaches can be used to estimate of panel data regression model is as follows:

\section{Pooled OLS Model (Common Model)}

Assumes that all cross-sections have similar coefficient (doesn't distinguish intercept and regression coefficients between the various cross-sections). As a consequence, the estimated coefficients may be biased as well as inconsistent. Therefore, Pooled OLS Model (Common Model) is not used in this research. 


\section{The Fixed Effects Model (FEM)}

The intercept in regression model is allowed to differ among individual or cross-sectional, unit may have some characteristic of its own. A disadvantage of FEM is that is consumes a lot of degrees of freedom (df) when the number cross-sectional units, $\mathrm{N}$, is very large. The FEM is appropriate in situations where the individual-specific intercept may be correlated with one or more regressors.

\section{Random Effects Model (REM) or Error Components Model (ECM)}

REM assumed that the intercept of an individual unit is a random drawing from much larger population with a constant mean value. One advantage of REM is economical in degrees of freedom, as we do not have to estimate $\mathrm{N}$ cross-sectional

Intercept, but just have to estimate the mean value of intercept. REM is appropriate when the intercept of each cross-sectional unit is uncorrelated with the regressors.

In conclusion, Pooled OLS Model is not properly enough to be used in panel data. So, Fixed Effect Model (FEM) or Random Effect Model (REM) will be selected as the most appropriate selection to determine the panel data model. The Hausman test can be used in order to decide between FEM and REM According to Gujarati (2009, 613). The hypothesis of Hausman test is as follow:

\section{$\mathrm{H}_{0}$ : Random Effect Model}

Ha: Fixed Effect Model

The Hausman test statistic is following chi-square statistic distribution with degree of freedom as much as $k$, number of independent variables according to Gujarati $(2009,605)$. The decision rule is:

$\mathrm{H}_{0}$ rejected if the value of the Hausman statistic $>$ critical value, then model following fixed effect model. $\mathrm{H}_{0}$ is not rejected if the value of the Hausman statistic < critical value, then model following random effect model.

\section{Normality Test}

According to Hair et al $(2010,71)$, Normality refers to the shape of the data distribution for an individual metric variable and its correspondence to the normal distribution, the benchmark for statistical methods. If the variation from the normal distribution is sufficiently large, all resulting statistical test are invalid, because normality is required to use the $F$ and $t$ statistics. Normality assumes that the disturbance term $u_{i}$ entering the regression model is normally distributed. Jarque-Bera (JB) test of normality is an asymptotic (large sample) test that can be used as statistic test to knowing whether the residuals are normally distributed or not based on OLS residuals According to Gujarati $(2009,132)$. This test is using measurement of skewness and kurtosis, where if data normally distributed, the value of skewness coefficient is close by 0 and kurtosis value approach 3 . Therefore can be expected the statistic value of JarqueBera to be 0 .

The formula is as follows:

$$
J B=n\left[\frac{S^{2}}{6}+\frac{(K-3)^{2}}{24}\right]
$$

According to Jarque-Bera test, residual data (the JB statistic value) are normally distributed if the chi-squares distribution with (df) 2 . If the value of JB less than value of chi-squares (df) 2 which is 5.991, it means that data is normally distributed. While if the value of JB greater than value of chi-squares (df) 2 which is 5.991, it means that data is not normally distributed. Normality test also can be seen from probability ( $p$-value), as follows:

$\mathrm{H}_{0}$ : The data is normally distributed

Ha: The data is not normally distributed

The result decision will be decided by rule:

If the $p$-value is $>0.05, \mathrm{H}_{0}$ is not rejected, then data is normally distributed

If the $p$-value is $\leq 0.05, \mathrm{H}_{0}$ is rejected, then data is not normally distributed

\section{Classical Assumption Test}

The basic framework of regression analysis is the Classical Linear Regression Model (CLRM). The CLRM is based on a set of assumptions, such as there is no multicollinearity among the independent variables, homoscedasticity, and no autocorrelation between the disturbances. So, according to those assumptions is expected that the model used in the analysis is the correct model, which stated in the class of Best Linear Unbiased Estimators (BLUE) under the OLS as standard least-squares estimator According to Gujarati $(2009,84)$.

\section{Breusch-Godfrey}

According to Gujarati and Porter (2009, 438), for avoiding some pitfall of the Durbin-Watson $d$ test of autocorrelation, can be used the Breusch-Godfreytest. The null hypothesis to be tested is always that there is no auto correlation, therefore the hypothesis of auto correlation test is as follows:

$\mathrm{H}_{0}: \rho=0$, means there is no autocorrelation Ha: $\rho \neq 0$, means there is autocorrelation.

\section{Panel Data Regression Model}

Panel data regression model is used in this research because this research is combining cross sectional and time series data. Multiple regression analysis is using as hypothesis testing in this research. According to Zikmund et al (2010, 584),"Multiple Regression Analysis is an analysis of association in which the effects of two or more independent variable on a single, interval-scaled dependent variable are investigated simultaneously". 
The estimated equation of Panel regression model in this research is as follows:

$Y_{i t}=\beta_{0}+\beta_{1} X_{1}+\beta_{2} X_{2}+\beta_{3} X_{3}+\beta_{4} X_{4}+\beta_{5} X_{5}+\beta_{6} X_{6}+\varepsilon_{i t}$

Where:

$\mathrm{Y}_{\text {it }} \quad=$ Financial Performance (Return On Assets)

$\beta_{0} \quad=$ Intercept or Constanta

$\beta_{1}, \beta_{2}, \beta_{3}, \beta_{4}, \beta_{5}=$ Slope or Coefficient Regression of

Variable Independent or the parameter to be estimated

$\mathrm{X}_{1} \quad=$ Leverage (Debt to Equity ratio)

$\mathrm{X}_{2} \quad=$ Liquidity (Current Ratio)

$\mathrm{X}_{3} \quad=$ Firm Size (Logarithm Natural of Total Assets)

$\mathrm{X}_{4} \quad=$ Firm Age (Number of years since establish)

$X_{5} \quad=$ Managerial Ownership

$\mathrm{X}_{6} \quad=$ Blockholder Ownership

$\varepsilon_{\mathrm{it}} \quad=$ Error Term

\section{Result AND ANALYSIS}

Table 2

Descriptive Statistics

\begin{tabular}{|l|c|c|c|c|}
\hline & Mean & Maximum & Minimum & $\begin{array}{c}\text { Std. Dev. } \\
\text { Observations }\end{array}$ \\
\hline ROA & 0.029910 & 0.106500 & -0.189700 & 0.065337 \\
\hline DER & 1.856584 & 11.99000 & 0.070000 & 2.237990 \\
\hline CR & 1.985078 & 10.26364 & 0.127349 & 2.652292 \\
\hline FS & 27.77446 & 29.65460 & 25.56912 & 1.436493 \\
\hline FA & 24.83333 & 33.00000 & 14.00000 & 5.411628 \\
\hline MO & 0.013409 & 0.073500 & 0.000001 & 0.027397 \\
\hline BO & 0.695915 & 0.953700 & 0.421300 & 0.149991 \\
\hline
\end{tabular}

Source: Eviews 7 Processed (Appendix)

Financial Performance (Proxy by Return on assets) variable has maximum value of 0.106500 , minimum value of 0.189700 , mean value of 0.029910 , and standard deviation value of 0.065337 during research period 2007-2012.

Leverage (Proxy by Debt to equity ratio) variable has maximum value of 11.99000 , minimum value of0.070000, mean value of 1.856584 , and standard deviation value of 2.237990 during research period 2007-2012. Liquidity (Proxy by Current ratio) variable has maximum value of 10.26364 , minimum value of 0.127349 , mean value of 1.985078 , and standard deviation value of 2.652292 during research period 2007-2012. Firm size variable has maximum value of 29.65460, minimum value of 25.56912, mean value of 27.77446 , and standard deviation value of 1.436493 during research period 2007-2012. Firm age variable has maximum value of 33.00000 , minimum value of 14.00000, mean value of 24.83333, and standard deviation value of 5.411628 during research period 20072012. Managerial Ownership variable has maximum value of 0.073500 , minimum value of 0,000001 , mean value of 0.013409 , and standard deviation value of 0.027397 during research period 2007-2012.Blockholder Ownership has maximum value of 0.953700 , minimum value of 0.421300 , mean value of 0.695915 , and standard deviation value of 0.149991during research period 2007-2012.

\section{Hausman Test Analysis}

Hausman test analysis is being used to determine the appropriate model.

Table 3

Hausman Test Result

\begin{tabular}{|l|c|c|c|}
\hline Test Summary & $\begin{array}{c}\text { Chi-Sq. } \\
\text { Statistic }\end{array}$ & $\begin{array}{c}\text { Chi-Sq. } \\
\text { d.f. }\end{array}$ & Prob. \\
\hline Cross-section Fixed & 21.206469 & 5 & 0.0007 \\
\hline
\end{tabular}

Source: Eviews 7 Processed (Appendix)

Based on table 4, Chi-square statistic value is 21.206469, and according to Chi-squares table value with alpha 0.05 and (d.f) is 11.07. So the null hypothesis $\left(\mathrm{H}_{0}\right)$ is rejected. This is appropriate with the result of probability value cross-section fixed0.0007which is smaller than alpha (0.05), then the null hypothesis $\left(\mathrm{H}_{0}\right)$ is rejected. It means the model is in Fixed Effect Model.

Breusch-Godfrey Test Result

\begin{tabular}{|l|l|l|l|}
\hline Obs*R-Squared & 2.293534 & Prob. Chi-Square(2) & 0.3177 \\
\hline
\end{tabular}

Source: Eviews 7 Processing (Appendix)

Based on table on above, the value of Obs*R-Squared is 2.293534 which smaller than Chi-squares table with (d.f) of 2 which is 5,991 and the probability value is 0.3177 which greater than alpha (0.05). It means that there is no autocorrelation problem occurred in the model.

Data Analysis and Hypothesis Testing of H7 (F-Statistic Testing)

$$
\mathrm{H}_{07}: \mathrm{b}_{1}=\mathrm{b}_{2}=\mathrm{b}_{3}=\mathrm{b}_{4}=\mathrm{b}_{5}=\mathrm{b}_{6}=0
$$

There is no significant effect of Leverage, Liquidity, Firm Size, Firm Age, Managerial Ownership and Blockholder Ownership to Financial Performance simultaneously.

$$
\mathrm{H}_{\mathrm{a} 7}: \mathrm{b}_{1} \neq \mathrm{b}_{2} \neq \mathrm{b}_{3} \neq \mathrm{b}_{4} \neq \mathrm{b}_{5} \neq \mathrm{b}_{6} \neq 0
$$

There is a significant effect of Leverage, Liquidity, Firm Size, Firm Age, Managerial Ownership and Blockholder Ownership to Financial Performance simultaneously.

The calculation of regression of Leverage, Liquidity, Firm Size, Firm Age, Managerial Ownership and Blockholder Ownership on Financial Performance can be seen in the Table 4.15 as follows:

Table 4

Coefficient of Determination

\begin{tabular}{|l|l|}
\hline R & 0.667302 \\
Adjusted R-Squared & 0.445292 \\
\hline
\end{tabular}

Source: Eviews 7 Processing (Appendix)

According to Table on above the coefficient of correlation (R) is 0.667302. It means that the relationship between Leverage, Liquidity, Firm Size, Firm Age, Managerial Ownership and Blockholder Ownership (simultaneously) and financial performance is positive correlation. 
Asian Business Review, Volume 5, Number 2/2015 (Issue 11)

ISSN 2304-2613 (Print); ISSN 2305-8730 (Online)

The value of coefficient of determination $\left(\mathrm{R}^{2}\right)$ is 0.445292 .

It means variation of dependent variable (Financial

Performance) can be explained by variation of independent variables (Leverage, Liquidity, Firm Size,

Firm Age, Managerial Ownership and Blockholder Ownership) is only 0.445292 or $44.52922 \%$ and the remaining $(0.554708$ or $55.4708 \%)$ is explained by others variation variables which is not included Sampling Proceduresof the regression model.

Table 5

Coefficient of Regression:

\begin{tabular}{|l|l|l|l|l|}
\hline Variable & Coefficient & Std. Error & t-Statistic & Prob. \\
\hline C & -0.764062 & 0.197159 & -3.875358 & 0.0006 \\
\hline DER & -0.000234 & 0.004505 & -0.051875 & 0.9590 \\
\hline CR & -0.000546 & 0.005704 & -0.095780 & 0.9244 \\
\hline FS & 0.026479 & 0.009756 & 2.714090 & 0.0111 \\
\hline FA & -0.002668 & 0.003035 & -0.879181 & 0.3865 \\
\hline MO & -0.505282 & 0.659183 & -0.766528 & 0.4496 \\
\hline BO & 0.191253 & 0.073303 & 2.609065 & 0.0142 \\
\hline
\end{tabular}

Source: Eviews 7 Processed (Appendix)

According to above table the multiple regression equation which also including panel data regression (with fixed effect model) as follows:

Yit $=b_{0}+b_{1} X_{1} i t+b_{2} X_{2} i t+b_{3} X_{3} i t+b_{4} X_{4} i t+b_{5} X_{5} i t+b_{6} X_{6} i t+\varepsilon_{i t}$

Financial Performance $=-0.764062-0.000234 \mathrm{DER}-$ $0.000546 \mathrm{CR}+0.026479 \mathrm{FS}-0.002668 \mathrm{FA}-0.505282 \mathrm{MO}+$ $0.191253 \mathrm{BO}+\varepsilon_{\mathrm{it}}$

The equation means that:

$\mathrm{b}_{0}=-0.764062$. It means if the variables value of Leverage, Liquidity, Firm Size, Firm Age, Managerial Ownership and Blockholder Ownership simultaneously toward Financial Performance are equal to zero (0), then the value of Financial Performance is equal to -0.764062 .

$b_{1}=-0.000234$. It means if the variable of Leverage is increased 1 unit, then financial performance will decrease 0.000234units, with other independent variables constant assumption.

$b_{2}=-0.000546$. It means if the variable of Liquidity is increased 1 unit, then financial performance will decrease 0.000546 units, with other independent variables constant assumption.

$b_{3}=0.026479$. It means if the variable of firm size is increased 1 unit, then financial performance will increase 0.026479units, with other independent variables constant assumption

$\mathrm{b}_{4}=-0.002668$. It means if the variable of firm age variable is increased 1 unit, then financial performance will decrease 0.002668units, with other independent variables constant assumption

$b_{5}=-0.505282$. It means if the variable of managerial ownership is increased 1 unit, then financial

performance will decrease 0.505282 units, with other independent variables constant assumption.

$b_{6}=0.191253$. It means if the variable of blockholder ownership is increased 1 unit, then financial performance will increase 0.191253 units, with other independent variables constant assumption.

Table 6

Coefficient of Regression Result:

\begin{tabular}{|lc|}
\hline F-statistic & 5.335400 \\
Prob(F-statistic) & 0.000819 \\
\hline
\end{tabular}

Source: Eviews 7 Processed (Appendix)

According to above of table, F-statistic has value 5.335400 which greater than F-table 2.43, hence the located in the area where $\mathrm{H}_{0}$ is rejected. It means $\mathrm{H}_{0}$ is rejected. This also supported by probability value result which is 0.000819 which smaller than alpha 0.05. Then, in conclusion is there is a significant effect of Leverage, Liquidity, Firm Size, Firm Age, Managerial Ownership and Blockholder Ownership to Financial Performance simultaneously.

\section{CONCLUSION}

Based on result and analysis done by researcher with sample property and real estate companies listed at Indonesia stock exchange during the period 2007 to 2012, then conclusion of the result of this research is as follows: Leverage

There is a significant effect of leverage to financial performance based on hypothesis testing of $\mathrm{H}_{1}$. This result is consistent with previous research of Liargovas \& Skandalis (2008), Dr.Amal Yassin Almajali et.al(2012), and Asad Abbas et.al(2013), which stated that leverage affect financial performance.

\section{Liquidity}

There is no significant effect of liquidity to financial performance based on hypothesis testing of $\mathrm{H}_{2}$. This result contradicts with previous research of Dr.Amal Yassin Almajali et.al(2012), which stated that liquidity affect financial performance.

\section{Firm Size}

There is no significant effect of firm size to financial performance based on hypothesis testing of $\mathrm{H}_{3}$. This result is contradicts with previous research of Liargovas \& Skandalis (2008), Prasetyantoko and Parmono (2008), Dr.Amal Yassin Almajali et.al(2012), and Asad Abbas et.al(2013), which stated that firm size affect financial performance.

\section{Firm Age}

There is a significant effect of firm age to financial performance based on hypothesis testing of $\mathrm{H}_{4}$. This result is contradicts with previous research of Dr.Amal Yassin Almajali et.al(2012), which stated that firm age does not affect financial performance.

\section{Managerial Ownership}

There is no significant effect of managerial ownership to financial performance based on hypothesis testing of $\mathrm{H}_{5}$. 
This result contradicts with previous research of Lee (2008) and prasetyantoko \& parmono (2008), which stated that managerial ownership, affect financial performance.

\section{Block holder Ownership}

There is no significant effect of block holder ownership to financial performance based on hypothesis testing of $\mathrm{H}_{6}$. This result contradicts with previous research of Asad Abbas (2013), which stated that block holder ownership affect financial performance.

\section{Simultaneously}

There is a significant effect of leverage, liquidity, firm size, firm age, managerial ownership and block holder ownership to financial performance based on hypothesis testing of $\mathrm{H}_{7}$.

\section{LIMITATIONS}

Researcher realizes that this research is still imperfect and limited. It is only using six independent variables that are considered affecting financial performance, while there are many other variables affecting financial performance. The sample of this research is less because there are many cross sections that are not in accordance with the criteria that researcher established. So it does not represent all of the emitters listed on the Indonesia stock exchange. This research only analyzes 6-years period data from 2007 to 2012 that may not reflect the comprehensive condition of the firms.

\section{RECOMMENDATIONS}

Based on research findings the following recommendations were presented for the next research related to financial performance:

Add some independent variables that may affect financial performance, more industries or some crosssectional and then increase research period.

\section{REFERENCES}

Abas, Asad.,Naqvi,A, Hasnain.,Mirza, Hasan , Hamad., 2013. Impact of Large Ownership on Firm Performance: A Case of non Finanacial Listed Companies of Pakistan., World Applied Science Journal, 21(8)

Aguilera, Ruth V. 2004. Corporate Governance, International Encyclopedia of Economic Sociology. London: Routledge

Agustinus, Prasetyantoko and Rachmadi, Parmono. 2008. Determinants of Corporate in Indonesia. Munich Personal RePEc Archive Paper No. 6777Performance of Listed Companies in Indonesia. Munich Personal RePEc Archive Paper No. 6777

Almajali, Amal Yassin., Alamro, Sameer Ahmed., Al-Soub, Yahya Zakarea. 2012. Factors Affecting the Financial Performance ofJordanian Insurance Companies Listed at Amman Stock Exchange. Journal of Management Research Macro Think Vol. 4, No. 2.

Anderson, David R., Sweeney, Dennis J., Williams, Thomas A. 2011. Statistics for Business and Economics. United States of America: South-Western, Cengage Learning.

Bodie, ZVI., Kane, Alex., Marcus, Alan J. 2011. Investments and Portfolio Management, Ninth Edition. United States of America: The McGraw-Hill Companies, Inc.
Brown, Keith C., Reilly, Frank K. 2009. Analysis of Investment and Management of Portfolio, Eight Edition. Canada: SouthWestern

Copeland et al.2005. Financial Theory and Corporate Policy, 14th edition. United States of America: Pearson Education, Inc.

Damodaran, Aswath. 2002. Investment Valuation. New York: John Wiley \& Sons. Inc.

Domash, Harry. 2010. Fire Your Stock Analysis!, Second Edition. New Jersey: Pearson Education. Inc.

Elmans, S C. 2012. Ownership Structure and Voluntary Disclosure in Europe. Erasmus University Rotterdam

Eng. L. L .,Mak Y.T, 2003. Corporate governance and Voluntary disclosure, Journal of Accounting and Public Policy, Volume 22, issue 4, Elsevier

Gitman, Lawrence J. 2012. Principles of Managerial Finance, Thirteenth Editon. England: Pearson Education Limited

Gujarati, Damodar N. 2010. Essentials of Econometrics. Singapore: The McGraw-Hill Companies, Inc.

Hair, Joseph F., William C. Black., Barry J. Babin., and Rolph E Anderson. 2010. Multivariate Data Analysis, Seventh Edition. New Jersey : Pearson Prentice Hall, Pearson Education International

Haugen, Robert A. 2001. Modern Investment Theory, Fifth Edition. . United States of America: Pearson Prentice Hall, Pearson Education International.

Kakani, Saha\& Reddy, 2001. Determinant of Financial Performance of Indian Corporate Sector in the Post Liberalization Era: An Exploratory Study, NSE Research initiative paper 5 SSRN

Lee, Sanghoon.2008. Ownership Structure and Financial Performance: Evidence from Panel Data of South Korea. Department of Economics, University of Utah, Salt Lake City, Utah, U.S.A.

Liargovas ,Panagiotis, \& Skandalis, Konstantinos, 2008. "Factors Affecting Firms' Financial Performance: The Case of Greece," Working Papers 0012, University of Peloponnese, Department of Economics

Ross, Stephen A., Westerfield, Radolph W., Jaffe, Jeffrey et al. 2009. Modern Financial Management, Eighth Edition. Singapore: The McGraw-Hill Companies, Inc.

Sekaran, Uma., Roger Bougie. 2009. Research Methods for Business - A Skill Building Approach. United Kingdom: John Wiley \& Sonds Ltd. Zikmund, William G., Babin, Barry J., Carr, Jon C et al.2010. Business Research Methods, Eighth Edition. United States of America: South-western, Cengage Learning.

Thomsen, S., Pedersen, T.,\&Kvist, H.K. 2006. Blockholder ownership: Effects on firm value in market and control based governance systems, Journal of Corporate Finance, p.246-269.

Wellalage, Nirosha Hewa, and Stuart Locke. 2012. Ownership Structure and Firm Financial Performance: Evidence from Panel Data in Sri Lanka. Journal of Business Systems, Governance and Ethics Vol 7, No 1.

White, Gerald I., Ashwinpaul C. Ondshi, Dov Fried. 2003. The Analysis and Use of Financial Statement, Third Edition. United States of America: John Wiley \& Sons, Inc.

White, Gerald I., Ashwinpaul C. Ondshi, Dov Fried. 2003. The Analysis and Use of Financial Statement, Third Edition. United States of America: John Wiley \& Sons, Inc.

Zikmund, William G., Babin, Barry J., Carr, Jon C et al. 2010. Business Research Methods, Eighth Edition. United States of America: South-western, Cengage Learning.

$$
\text { --0-- }
$$

